\title{
Portakal Üretim Sürecinin Termodinamik Değerlendirilmesi; Yeni Bir Yaklaşım
}

\author{
Hasan Yildizhan ${ }^{1 *}$ \\ ${ }^{1}$ Barış AB Proje Danışmanlığı, Adana, Türkiye (ORCID: 0000-0003-0272-980X)
}

(İlk Geliş Tarihi 3 Şubat 2019 ve Kabul Tarihi 1 Mart 2019)

(DOI: 10.31590/ejosat.521449)

ATIF/REFERENCE: Yıldızhan, H. (2019). Portakal Üretim Sürecinin Termodinamik Değerlendirilmesi; Yeni Bir Yaklaşım. Avrupa Bilim ve Teknoloji Dergisi, (15), 96-102.

\section{$\ddot{O} \mathbf{z}$}

Günümüzde çevrenin kirletilmemesi ve doğal kaynakların tüketilmemesi için sürdürebilir tarım uygulamalarıyla ilgili çalışmalar artmaktadır. Son yıllarda sürdürülebilir tarım uygulamaları için geliştirilen kümülatif ekserji tüketimi ile ilgili analiz çalışmaları artmıştır. Kümülatif ekserji tüketimi yaklaşımı, mahsul üretim süreçlerinde kullanılan girdilerin tasarruf potansiyelini tespit etmek ve böylece mahsullerin üretim süreçlerini iyileştirmede önemli bir metottur. Bu çalışmanın amacı portakal üretim sürecini, kümülatif ekserji tüketimi yaklaşımıyla değerlendirmektir. Bu çalışmada, portakal üretim süreci için kümülatif enerji tüketimi, kümülatif ekserji tüketimi ve kümülatif $\mathrm{CO}_{2}$ emisyon değerleri hesaplanmış ve değerlendirilmiştir. Portakal üretim sürecinde tarım ilacının kullanımından dolayı gerçekleşen kümülatif enerji ve ekserji tüketimleri ile kümülatif $\mathrm{CO}_{2}$ emisyonu çok fazla bulunmuştur. Sonuçlar, portakal üretim sürecinde çiftçilerin tarım ilacı kullanırken optimum düzeyde uygulama yapmaları önemli olduğunu göstermektedir.

Anahtar Kelimeler: Portakal üretimi, Tarım ilacı, Kümülatif ekserji tüketimi.

\section{Thermodynamic Evaluation of Orange Production Process; a New Approach}

\begin{abstract}
Nowadays, studies on sustainable agricultural practices are increasing in order not to pollute the environment and not to consume natural resources. In recent years studies on cumulative exergy consumption developed for sustainable agricultural practices have increased. The cumulative exergy consumption approach is an important method in determining of saving potential of inputs used in crop production processes and thereby improving the production processes of crops. The aim of this study is to evaluate the orange production process with cumulative exergy consumption approach. Cumulative energy consumption, cumulative exergy consumption and cumulative $\mathrm{CO}_{2}$ emission values were calculated and evaluated. The results on the cumulative energy, exergy consumption and cumulative $\mathrm{CO}_{2}$ emissions due to the use of pesticide application during the orange production process were found to be very high. As a result it should be noted that in the process of orange production, it is important for farmers to make optimum use when using pesticides.
\end{abstract}

Keywords: Orange production, Pesticides, Cumulative exergy consumption.

\footnotetext{
* Sorumlu Yazar: Barış AB Proje Danışmanlığı, Adana, Türkiye, ORCID: 0000-0003-0272-980X, hasanydhn@ @otmail.com
} 


\section{Giriş}

Fosil yakıtların sonlu olması, maliyetlerinin sürekli artması ve çevre kirliliğine sebep olmaları gibi olumsuz özellikleri nedeni ile tarımda ağırlıklı olarak fosil esaslı enerji kaynaklarıyla üretim yapılması sürdürülebilir bir yöntem değildir (Taşkın ve Vardar, 2016). Çözüm yöntemi olarak tarımda fosil esaslı girdilerin kullanımının terk edilmesi veya azaltılması, bunun yerine yenilenebilir esaslı girdilerin kullanılması gerekmektedir. Bununla birlikte tarımda enerji etkinliğinin arttırılması, enerji kaynaklarının kullanımında tasarruf yapılmasını sağlamaktadır. Bu durum da tarım uygulamalarından kaynaklanan çevresel sorunların azaltılmasını teşvik etmektedir. Enerjinin etkin kullanılması, aynı iş çıktısı değişmeden enerji kullanımının azaltılması olarak gerçekleşir (Öztürk ve ark., 2010). Çiftçilerin tarım uygulamalarında enerji kaynaklarını gelişi güzel tüketmek yerine enerji kaynaklarını bilinçli olarak tüketmeleri gerekmektedir. Böylece tarımda etkin enerji kullanımı sağlanmış olacaktır.

Günümüzde çevrenin kirletilmemesi ve doğal kaynakların tüketilmemesi için sürdürebilir tarım uygulamalarıyla ilgili çalışmalar artmaktadır. Sürdürebilir tarım kavramı, hem bugün hem de gelecek nesiller için gerekli olan doğal kaynakların korunması ve böylece insanların ihtiyacı olan besinlerin karşılanmasıdır (Eryılmaz ve Kılıç, 2018). Sürdürülebilir tarım uygulamalarında bir çok araştırmacı yenilenebilir enerji kaynaklarının tarım uygulamalarına adapte edilmesi hususunda çalışmalar yapmıştır (Bardi ve ark., 2013). Sürdürülebilir tarım uygulamaları kapsamında üretim süreçleri için yeni değerlendirme metodu olarak kümülatif ekserji tüketim analizi yapılmaktadır (Yildizhan, 2018; Yildizhan ve Taki, 2018; Taki ve Yildizhan, 2018; Yildizhan, 2017). Kümülatif ekserji tüketimi, sistem sınırları çerçevesinde bir ürünün hammaddeden son haline gelene kadar tüm süreç boyunca tüketilen ekserjilerin toplamı olarak tarif edilmektedir (Szargut, 2005). Kümülatif ekserji tüketiminin azaltılması daha az doğal kaynakların kullanılması anlamina gelmektedir (Hoang ve Prasada, 2010).

$\mathrm{Bu}$ çalışmanın amacı portakal üretim sürecini kümülatif ekserji tüketimi yaklaşımıyla değerlendirmektir. Çalışmada, portakal üretim süreci için kümülatif enerji tüketimi, kümülatif ekserji tüketimi ve kümülatif $\mathrm{CO}_{2}$ salınım değerleri hesaplanmış ve değerlendirilmiştir. Çalışma kapsamında, portakal üretim sürecinin geliştirilmesi için kullanılan girdilerin etkileri yorumlanmıştır. Bu çalışma mahsul üretim süreçlerinin geliştirilmesine yönelik yapılan araştırmalara önemli literatür katkı sağlayacaktır.

\section{Materyal ve Metot}

Tarımda her birim operasyon kapsamında kütle, enerji ve ekserji denge denklemleri; Kümülatif enerji tüketimi (CEnC), Kümülatif ekserji tüketimi $(\mathrm{CExC})$ ve kümülatif karbondioksit emisyonunu $\left(\mathrm{CCO}_{2} \mathrm{E}\right)$ belirlenmesi için kullanılır. Söz konusu denge denklemleri aşağıda verilmiştir (Dincer ve ark., 2004; Balkan ve ark. 2005; Wall, 2003; Ozilgen ve Sorgüven, 2011).

\section{Kütle dengesi:}

$\sum m_{\text {in }}=\Sigma m_{\text {out }}$

\section{Enerji dengesi:}

$\Sigma(m h)_{\text {in }}-\Sigma(m h)_{\text {out }}=W-Q$

\section{Ekserji dengesi:}

$\Sigma(m b)_{\text {in }}-\Sigma(m b)_{\text {out }}+\Sigma\left(1-\frac{T_{\mathrm{o}}}{T_{\mathrm{k}}}\right) Q_{\mathrm{k}}-W=I$

Yukarıdaki denklemlerde $m$ kütleyi, $h$ entalpiyi, $b$ kimyasal ekserjiyi, $W$ işi, $I$ ekserji kaybını, $T_{o}$ ortam sıcaklığını, $T_{k}$ kaynak sıcaklığını $Q_{k}$ 1sıyı ifade etmektedir.

Bir ton portakal üretimi için kullanılan girdiler ve miktarları ile ilgili veriler Mohammadshirazi ve arkadaşlarının çalışmasından alınmıştır. Belirtilen veriler Tablo 1'de verilmiştir (Mohammadshirazi ve ark., 2015). 


\begin{tabular}{|c|l|}
\hline 1. Kimyasal Gübreler & \\
\hline (a) Azot $(\mathrm{N})(\mathrm{kg})$ & 7.94 \\
\hline (b) Fosfor $\left(\mathrm{P}_{2} \mathrm{O}_{5}\right)(\mathrm{kg})$ & 3.92 \\
\hline (c) Potasyum $\left(\mathrm{K}_{2} \mathrm{O}\right)(\mathrm{kg})$ & 5.05 \\
\hline 2. Tarımsal ilaçlar $(\mathrm{kg})$ & 6.92 \\
\hline 3. Elektrik kullanımı (MJ) & 242.13 \\
\hline 4. Dizel kullanımı (L) & 1.39 \\
\hline
\end{tabular}

Çalışmada kümülatif enerji, ekserji tüketimleri ve karbondioksit salıııı için gerekli veriler ilgili çalışmalardan elde edilmiştir. (Ozilgen ve Sorgüven, 2011 ; Çengel, 2006; Berthiaume ve Bouchard, 1999; Helsel, 1992; Wittmus ve ark., 1975; Pimentel, 1991; Kongshaug, 1998; Ozilgen ve Sorgüven, 2016). Kullanılan değerler Tablo 2'de verilmiş̧tir.

Tablo 2. Her Girdi için Belirli CEnC, CExC ve $\mathrm{CCO}_{2}$ E Değerleri

\begin{tabular}{|c|c|c|c|}
\hline Girdiler & CEnC & CExC & $\mathrm{CCO}_{2} \mathrm{E}$ \\
\hline $\begin{array}{l}\text { Kimyasal Gübreler } \\
\text { - Azot }(\mathrm{N}) \\
\text { - Fosfor }\left(\mathrm{P}_{2} \mathrm{O}_{5}\right) \\
\text { - Potasyum }\left(\mathrm{K}_{2} \mathrm{O}\right)\end{array}$ & $\begin{array}{l}78.2 \mathrm{MJ} / \mathrm{kg} \text { (Ozilgen ve } \\
\text { Sorgüven, 2011) } \\
17.5 \mathrm{MJ} / \mathrm{kg} \text { (Ozilgen ve } \\
\text { Sorgüven, 2011) } \\
13.8 \mathrm{MJ} / \mathrm{kg} \text { (Ozilgen ve } \\
\text { Sorgüven, 2011) }\end{array}$ & $\begin{array}{l}32.7 \mathrm{MJ} / \mathrm{kg} \text { (Çengel, 2006) } \\
7.52 \mathrm{MJ} / \mathrm{kg} \text { ( Berthiaume ve } \\
\text { Bouchard, 1999) } \\
4.56 \mathrm{MJ} / \mathrm{kg} \text { (Berthiaume } \\
\text { ve ark., 2001) }\end{array}$ & $\begin{array}{l}0.09 \text { kg/kg (Helsel, 1992) } \\
0.15 \mathrm{~kg} / \mathrm{kg} \text { (Helsel, 1992) } \\
0.51 \mathrm{~kg} / \mathrm{kg} \text { (Helsel, 1992) }\end{array}$ \\
\hline $\begin{array}{l}\text { Kimyasallar } \\
\text { - Tarım ilacı }\end{array}$ & $\begin{array}{l}\text { 198.8 MJ/kg (Wittmus ve ark., } \\
1975)\end{array}$ & $\begin{array}{l}7.52 \mathrm{MJ} / \mathrm{kg} \\
\text { (Pimentel, 1991) }\end{array}$ & $\begin{array}{l}5.1 \quad \mathrm{~kg} / \mathrm{kg} \\
\text { (Kongshaug, 1998) }\end{array}$ \\
\hline Dizel yakıtı & $\begin{array}{rl}57.5 & \mathrm{MJ} / \mathrm{kg} \text { (Wittmus ve ark., } \\
1975) & \end{array}$ & $53.2 \mathrm{MJ} / \mathrm{kg}$ (Çengel, 2006) & $0.94 \mathrm{~kg} / \mathrm{kg}$ (Kongshaug, 1998) \\
\hline Elektrik & $1 \mathrm{MJ} / \mathrm{MJ}$ (Çengel, 2006) & 4.17 MJ/MJ (Çengel, 2006) & $\begin{array}{l}0.14 \mathrm{~kg} / \mathrm{MJ} \text { (Ozilgen ve } \\
\text { Sorgüven, 2016) }\end{array}$ \\
\hline
\end{tabular}

\section{Araştırma Sonuçları ve Tartışma}

$\mathrm{Bu}$ çalışma ile portakal üretim sürecinde, yer alan girdiler için enerji, ekserji kullanımları ve karbon dioksit salınım değerleri tespit edilmiş ve değerlendirilmiştir. Portakal üretim süreci kapsamında gerçekleşen kümülatif enerji tüketimine yönelik sonuçlar Şekil 1'de verilmiştir. Şekil 1'e bakıldığında portakal üretiminde en fazla enerji kullanımı tarım ilacı ile gerçekleşmiştir. Portakal üretim sürecinde tarım ilacının kullanım değeri $1376.11 \mathrm{MJ} /$ ton'dur. Tarım ilacını sırasıyla azot gübresi (621.6 MJ/ton), elektrik (242.13 MJ/ton), dizel (80.23 MJ/ton), potasyum gübresi $(69.73 \mathrm{MJ} /$ ton) ve fosfor gübresi (68.64 MJ/ton) takip emektedir. Toplam kimyasal gübrelerin kullanım değeri $760 \mathrm{MJ} /$ ton'dur. Portakal üretim sürecinde kimyasallardan (tarım ilacı) sonra en fazla kümülatif enerji tüketimi, kimyasal gübrelerin kullanımıyla gerçekleşmiştir. Bununla birlikte portakal üretim sürecinde toplam kümülatif enerji tüketimi $2458.44 \mathrm{MJ} /$ ton olarak gerçekleşmiştir.

Mohammadshirazi ve arkadaşların çalışmasında, portakal üretim sürecinde en fazla enerji kullanımı kimyasal gübrelerde olmuştur (Mohammadshirazi ve ark. 2015). Kimyasal gübreden sonra en fazla enerji kullanımı, tarım ilacı kullanımında gerçekleşmiştir. Sonuç olarak hem bu çalışmada hem de Mohammadshirazi ve arkadaşlarının çalışmasında en çok enerji tüketimi tarım ilacı ve kimyasal gübrelerin kullanımıyla gerçekleşmektedir. 
Kümülatif enerji tüketimi kapsamında başka mahsul ürünleri için yapılan çalışmalarda; Yildizhan, çileğin sera ve tarlada kümülatif enerji tüketimi için yaptığ çalışmada, tarlada 1 ton çilek üretim sürecinde en fazla enerji tüketimi kimyasal gübre ile gerçekleşirken sera şartlarında 1 ton çilek üretimi için en fazla enerji tüketimi elektrik kullanımıyla olduğunu belirtmiştir (Yildizhan, 2018). Taki ve Yıldızhan, 1 ton salatalığın sera şartlarında üretim süreciyle ilgili yaptıkları çalışmada ise en fazla enerji tüketiminin dizel kullanımıyla gerçekleştiğini bildirmişlerdir (Taki ve Yildizhan, 2018). Yapılan diğer bir çalışmada 1 ton patates için en fazla enerji tüketiminin kimyasal gübre kullanımıyla gerçekleştiğini bildirilmiştir (Yildizhan, 2017). Yildizhan ve Taki (2018), 1 ton domates üretimi için yaptıkları çalışmada enerji tüketimi kapsamında, kimyasal gübre kullanımının en fazla kümülatif enerji tüketimine sahip olduğunu belirtmişlerdir. Bu sonuçlar, mahsule ve üretim şartlarına göre girdilerin enerji tüketim miktarlarında değişiklik gösterdiğini işaret etmektedir.

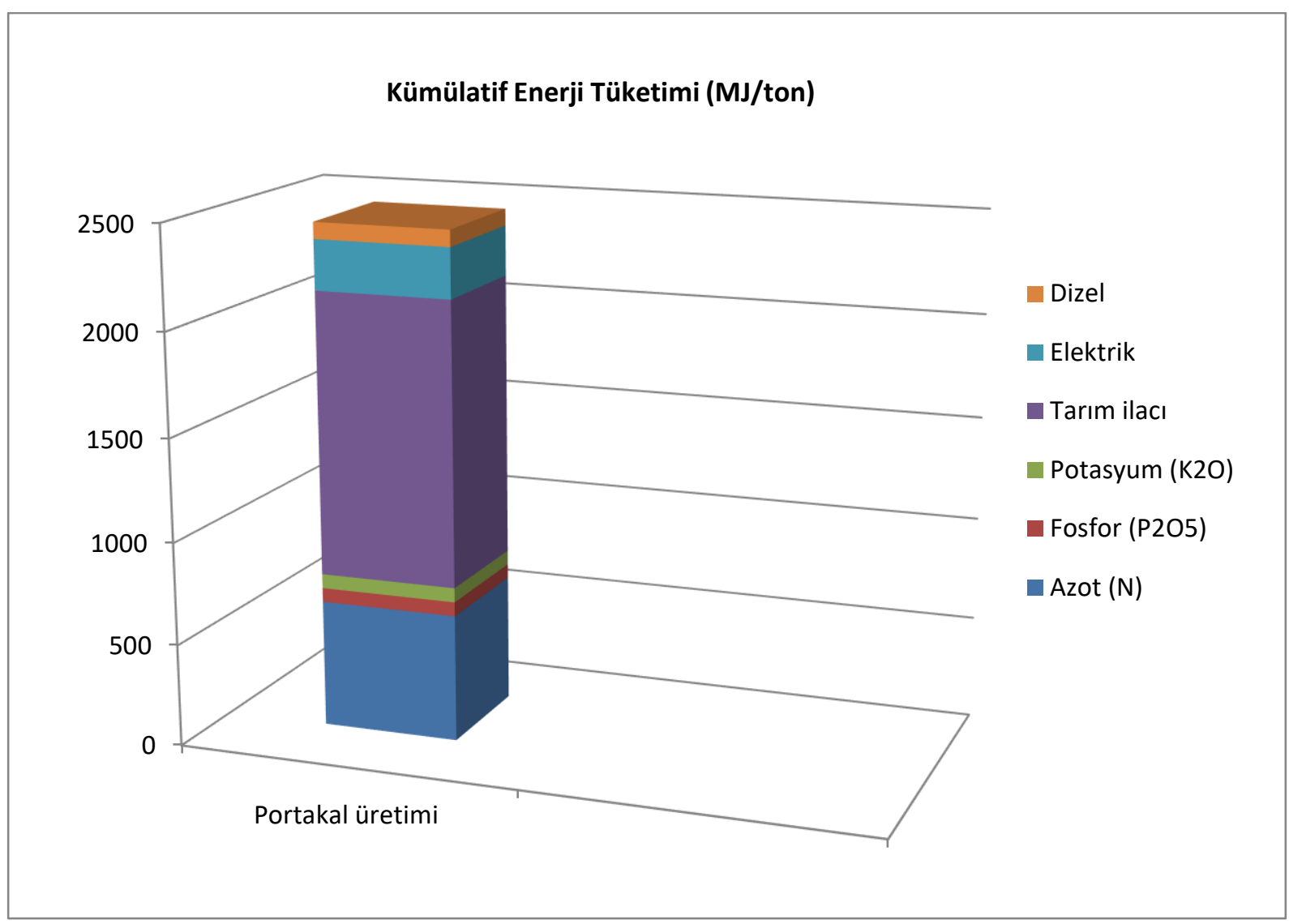

Şekil 1. 1 Ton Portakal Üretimi için Kümülatif Enerji Tüketim Sonuçları

1 ton portakal üretiminde kullanılan girdilerin kümülatif ekserji tüketim değerleri Şekil 2'de verilmiştir. Şekil 2'ye bakıldığında en fazla kümülatif ekserji tüketimi azot gübresinin kullanımında olmuştur. Azot gübresinin kümülatif ekserji tüketimi $259.92 \mathrm{MJ} /$ ton'dur. Azot gübresini tarım ilacı takip etmiştir. Tarım ilacının kümülatif ekserji tüketimi $52.05 \mathrm{MJ} /$ ton'dur. Diğer girdilerin kümülatif ekserji tüketimleri sırasıyla; elektrik kullanımı $46 \mathrm{MJ} /$ ton, fosfor gübresi $29.49 \mathrm{MJ} /$ ton, potasyum gübresi $23.04 \mathrm{MJ} /$ ton ve dizel kullanımı $12.27 \mathrm{MJ} /$ ton'dur. 1 ton portakal üretim sürecinde gerçekleşen toplam kimyasal gübre kullanımının kümülatif ekserji tüketimi 312.45 MJ'dur. 1 ton portakal üretimi için gerçekleşen toplam kümülatif ekserji tüketimi değeri ise $422.77 \mathrm{MJ}$ 'dur. Bu sonuçlar, 1 ton portakal üretiminde kimyasal gübre kullanımından dolayı kaynaklanan kümülatif ekserji tüketiminin ön planda olduğu sonucunu vermiştir. Bununla birlikte, portakal üretim süreci kapsamında, kümülatif enerji tüketiminde olduğu gibi kümülatif ekserji tüketiminde de tarım ilacının kullanımı yüksek düzeydedir.

Yildizhan (2018), çileğin tarlada ve sera şartlarında toplam kümülatif ekserji tüketimini sırasıyla $14178.5 \mathrm{MJ} /$ ton ve $8743 \mathrm{MJ} /$ ton olarak tespit etmiştir. Çilek üretiminde en çok ekserji tüketiminin sera şartlarında elektrik kullanımında (6768 MJ/ton) ve tarlada ise topak (pellet) gübre $(5430 \mathrm{MJ} /$ ton) kullanımında gerçekleştiğini belirtmiş̧ir (Yildizhan, 2018). Aynı araştırmacının diğer bir çalışmasında patatesin toplam kümülatif ekserji tüketimini 1 ton üretimi için $4832.5 \mathrm{MJ}$ olarak tespit edilmiştir. Aynı çalışmada en fazla kümülatif ekserji tüketimi topak gübre (2969.57 MJ/ton) kullanımıyla gerçekleşmiştir. Çalışmada en düşük kümülatif ekserji tüketimi tarım ilaçlarının (1.32 MJ/ton) kullanımıyla gerçekleşmiştir (Yildizhan, 2017).

Yıldızhan ve Taki (2018), Türkiye'nin farklı bölgeleri için domates üretim süreçlerinin kümülatif ekserji tüketimlerini analiz etmişlerdir. En fazla kümülatif ekserji tüketimi Güney Marmara bölgesinde ve tarla üretim koşullarında $1075 \mathrm{MJ} /$ ton olarak gerçekleşmiştir. Aynı çalışmada Antalya'da sera üretim koşullarında $731 \mathrm{MJ} /$ ton ve Tokat'ta tarla üretim koşullarında $592 \mathrm{MJ} /$ ton olarak tespit edilmiştir. Güney Marmara bölgesinde domates üretim sürecinde en fazla kümülatif ekserji tüketimi sulamada (598 MJ/ton) gerçekleşmiştir. Tüm bölgelerde tarım ilaçlarının kümülatif ekserji tüketim değerleri düşük düzeydedir (Yildizhan ve Taki, 
2018). Taki ve Yildizhan (2018), sera koşullarında salatalık üretim sürecinin toplam kümülatif ekserji tüketimini $4648 \mathrm{MJ} /$ ton olarak tespit etmişlerdir. En fazla kümülatif ekserji tüketimi dizel (1981 MJ/ton) kullanımında olmuştur. Dizeli, doğal gaz (1820 MJ/ton) kullanımı takip etmiştir (Taki ve Yildizhan, 2018).

Portakal üretim sürecinde kümülatif ekserji tüketimi kapsamında kimyasal gübre ile beraber tarım ilacının kullanımı ön plandadır. Bu sonuç önceki çalışmalardan farklıdır. Önceki çalışmalarda, farklı mahsullerin üretim süreçleri kapsamında tarım ilacının kullanımı düşük düzeyde gerçekleşmiştir. Sonuç olarak mahsullerin cinsi ve üretim koşullarına göre kümülatif ekserji tüketim değerleri değişmektedir.

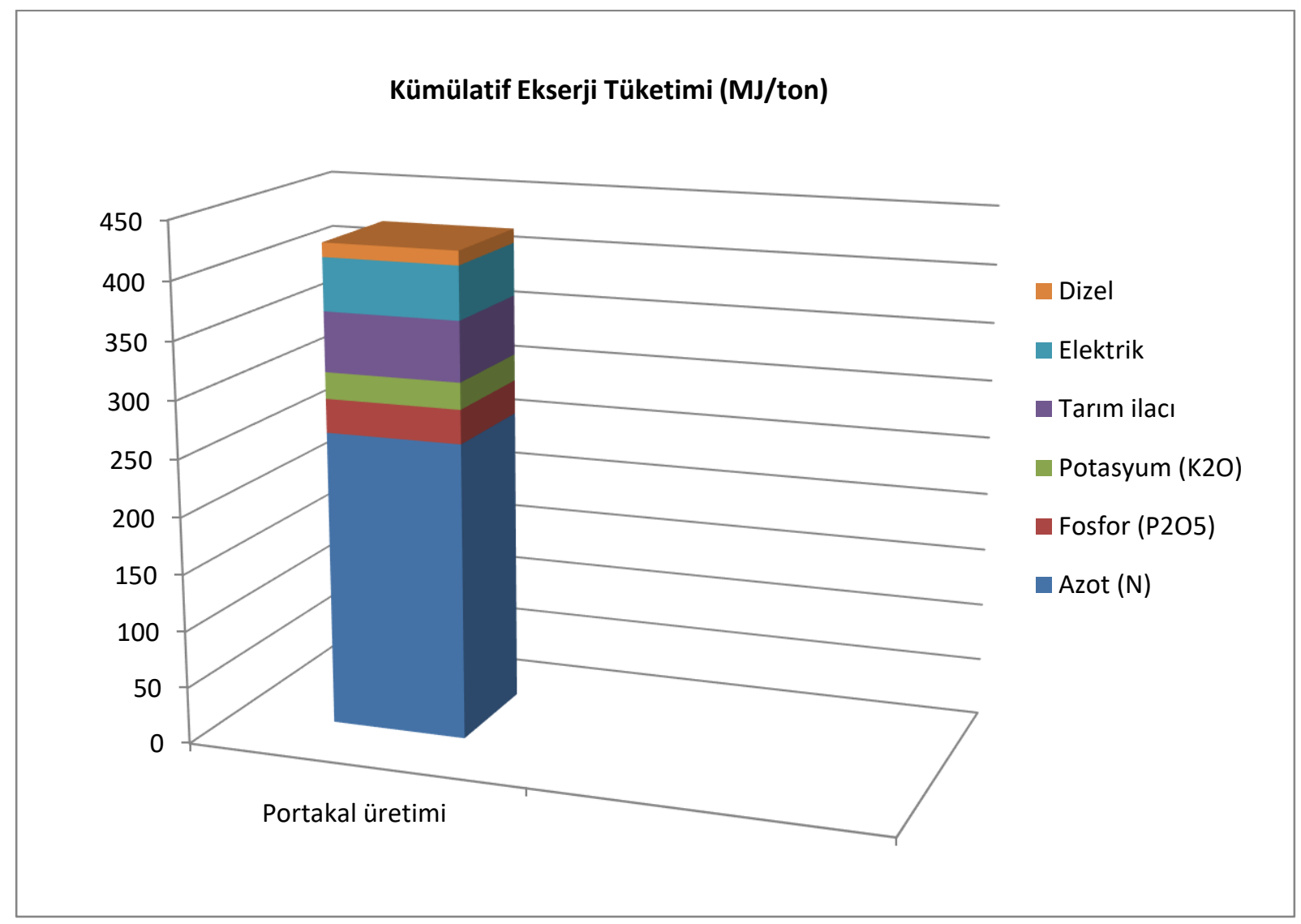

Şekil 2. 1 Ton Portakal Üretimi için Kümülatif Ekserji Tüketimi Sonuçları

1 ton portakal üretim sürecinde gerçekleşen kümülatif $\mathrm{CO}_{2}$ emisyonu ile ilgili sonuçlar Şekil 3 'te verilmiştir. Portakal üretim sürecinde en fazla kümülatif $\mathrm{CO}_{2}$ emisyonu tarım ilacının kullanımıyla gerçekleşmiştir. Tarım ilacının kullanımından dolayı gerçekleşen kümülatif $\mathrm{CO}_{2}$ emisyonu $35.3 \mathrm{~kg} /$ ton olarak tespit edilmiştir. Diğer girdilerin kullanımından dolayı gerçekleşen kümülatif $\mathrm{CO}_{2}$ emisyonlar; elektrik kullanımın $33,89 \mathrm{~kg} /$ ton, potasyum kullanımında $2.57 \mathrm{~kg} / \mathrm{ton}$, dizel kullanımında $1.31 \mathrm{~kg} /$ ton, azot gübreden $0.71 \mathrm{~kg} /$ ton ve fosfor gübreden $0.58 \mathrm{~kg} /$ ton olarak tespit edilmiştir. Sonuçlar, portakal üretimde gerçekleşen kümülatif $\mathrm{CO}_{2}$ emisyonunda tarım ilacı ve elektrik kullanımı ön planda olduğunu göstermektedir.

Yildizhan (2018), 1 ton çilek üretim için sera ve tarla koşullarında kümülatif $\mathrm{CO}_{2}$ emisyonları sırasıyla $506.07 \mathrm{~kg}$ ve $243.06 \mathrm{~kg}$ olarak tespit etmiştir. 1 ton çilek üretimi için sera koşullarında elektrik kullanımında (227.22 kg) ve tarla koşullarında sulamadan (112.51 kg) dolayı en fazla kümülatif $\mathrm{CO}_{2}$ emisyonuna sebep olduğunu belirtmiştir (Yildizhan, 2018). Yildizhan (2017), bir ton patates üretim sürecinde gerçekleşen kümülatif $\mathrm{CO}_{2}$ emisyonunu $67.3 \mathrm{~kg}$ olarak tespit etmiştir. Aynı çalışmada en fazla kümülatif $\mathrm{CO}_{2}$ emisyonunun, sulamadan $(27.89 \mathrm{~kg} / \mathrm{ton})$ kaynaklandığ

Yildizhan ve Taki (2018), domates üretim sürecinin Türkiye'de farklı bölgeler için yapmış oldukları çalışmada en fazla kümülatif $\mathrm{CO}_{2}$ emisyonunun Güney Marmara bölgesinde gerçekleştiğini belirtmişlerdir. Güney Marmara'da sulamadan dolayı en fazla $\mathrm{CO}_{2}$ emisyonu olmuştur. Güney Marmara'yı, Tokat (26.25 kg/ton) ve Antalya (25.42 kg/ton) takip etmiştir. Tokat ve Antalya'da en fazla $\mathrm{CO}_{2}$ emisyonuna sebep olan girdiler sırasıyla; sulama ve elektrik kullanımından dolayı gerçekleşmiştir. Bununla birlikte, Antalya'da domates üretimi sera koşullarında gerçekleşmiştir. Taki ve Yildizhan (2018), sera koşullarında salatalık üretiminde gerçekleşen kümülatif $\mathrm{CO}_{2}$ emisyonunu $175 \mathrm{~kg}$ /ton olarak tespit etmişlerdir. En fazla $\mathrm{CO}_{2}$ emisyonuna sebep olan girdinin ise doğal gaz kullanımıyla gerçekleştiğini belirtmişlerdir. 


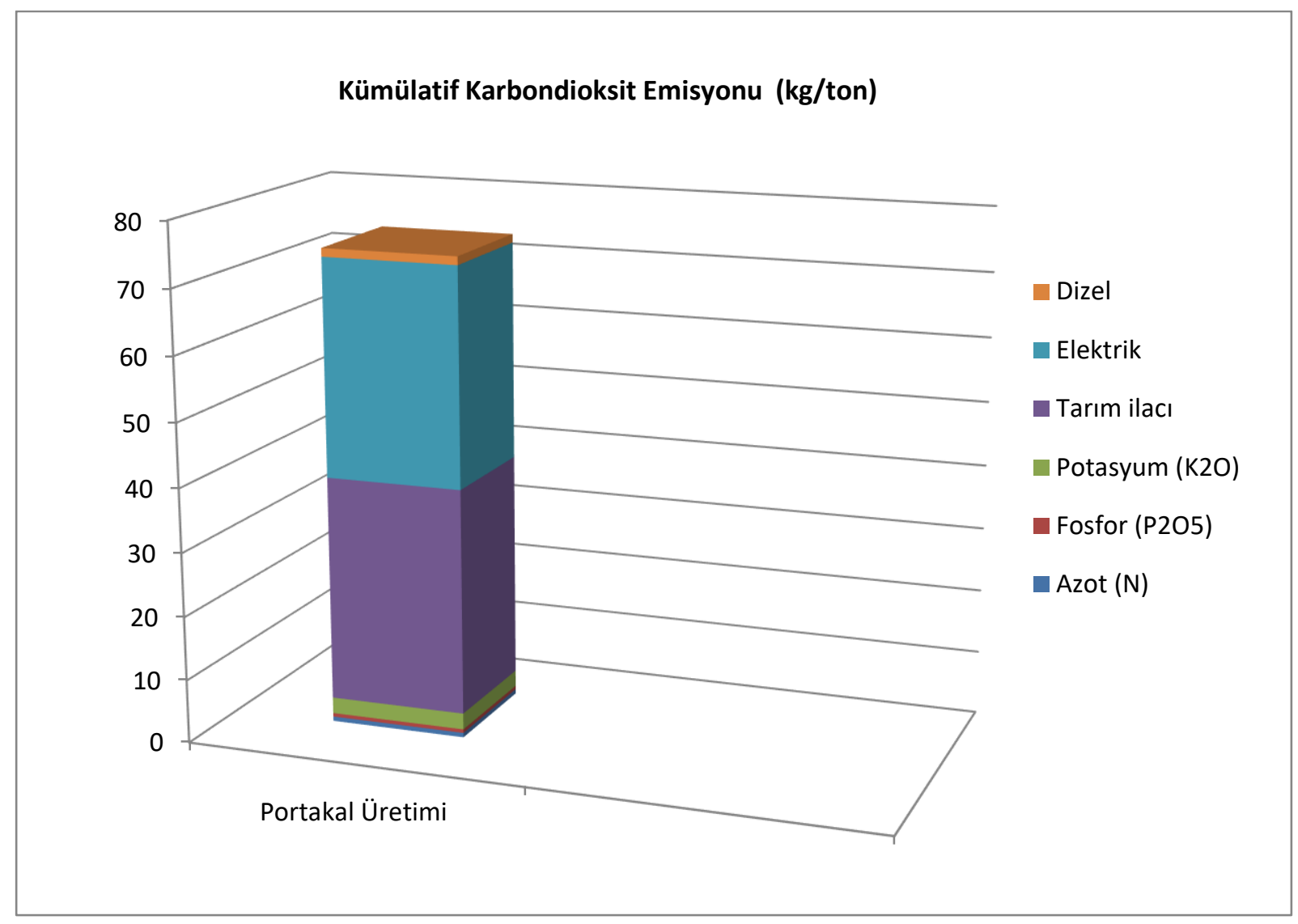

Şekil 3. 1 Ton Portakal Üretimi için Kümülatif Karbon Dioksit Salınım Sonuçları

\section{Sonuç}

Kümülatif ekserji tüketimi yaklaşımı, mahsul üretim süreçlerinde kullanılan girdilerin tasarruf potansiyelini tespit etmek ve böylece mahsullerin üretim süreçlerini iyileştirmede önemli bir metottur. Ayrıca, kümülatif ekserji tüketim analizinin sürdürülebilir tarım uygulamalarının analizinde kullanılması faydalı olacağı düşünülmektedir.

$\mathrm{Bu}$ çalışmada portakal üretim süreci için kümülatif enerji ve ekseji tüketimleri ile kümülatif $\mathrm{CO}_{2}$ emisyon değerleri tespit edilmiştir. Ayrıca bu çalışmanın sonuçları benzer metot kullanılarak yapılan farklı mahsullerin analiz sonuçlarıyla kıyaslanmıştır.

Çalışmada bir ton portakal üretim süreci için gerçekleşen toplam kümülatif enerji kullanımı $2458.44 \mathrm{MJ}$ tespit edilmiştir. Portakal üretim sürecinde en fazla kümülatif enerji tüketimi tarım ilacının kullanımında gerçekleşmiştir. Tarım ilacının kümülatif enerji tüketim değeri $1376.11 \mathrm{MJ} /$ ton olarak tespit edilmiştir. Bununla birlikte, 1 ton portakal üretimi için gerçekleşen toplam kümülatif ekserji tüketim değeri ise $422.77 \mathrm{MJ}$ olarak bulunmuştur. En fazla kümülatif ekserji tüketimi, azot gübresinin kullanımıyla gerçekleşmiştir. Azot gübresinin kullanımıyla gerçekleşen kümülatif ekserji tüketimi $259.92 \mathrm{MJ} /$ ton'dur. Azot gübresini tarım ilacı takip etmiştir. Tarım ilacının kümülatif ekserji tüketimi $52.05 \mathrm{MJ} /$ ton'dur.

Bir ton portakal üretim süreci için gerçekleşen toplam kümülatif $\mathrm{CO}_{2}$ emisyonu $74.36 \mathrm{~kg}$ olarak tespit edilmiştir. Portakal üretim sürecinde en fazla $\mathrm{CO}_{2}$ emisyonuna sebep olan girdi tarım ilacının kullanımında olmuştur. Tarım ilacının kullanımından dolayı gerçekleşen kümülatif $\mathrm{CO}_{2}$ emisyonu $35.3 \mathrm{~kg}$ /ton olarak tespit edilmiştir. Tarım ilacından sonra en fazla kümülatif $\mathrm{CO}_{2}$ emisyonuna sebep olan girdi ise elektrik kullanımıdır. Elektrik kullanımından kaynaklanan kümülatif $\mathrm{CO}_{2}$ emisyonu $33.89 \mathrm{~kg} / \mathrm{ton}$ olarak tespit edilmiştir.

Literatürde benzer çalışmalarla kıyaslandığında portakal üretim sürecinde diğer mahsullere kıyasla tarım ilacının kullanımı ön plandadır. Portakal üretim sürecinde tarım ilacının kullanımından dolayı gerçekleşen kümülatif enerji ve ekserji tüketimleri ile kümülatif $\mathrm{CO}_{2}$ emisyonu çok fazladır. Sonuç olarak, portakal üretim sürecinde çiftçilerin tarım ilacı kullanırken optimum düzeyde uygulama yapmaları önemlidir. Bu sebeple portakal üretim sürecinde çiftçilerin gelişi güzel kullanımından ziyade, tavsiyeye uygun ve reçeteli ilaç kullanması gerekmektedir. Bu durum hem insan sağlığı açısından hem de doğal denge açısından önem arz etmektedir.

Mahsullerin üretim süreçleri birbirlerinden farklılık göstermektedir. Bu durum üretilen mahsullerin kimyasal yapılarıla doğrudan ilişkilidir. Bundan sonraki çalışmalar için araştırmacılara, mahsullerin kimyasal yapılarıyla ilgili olarak kullanılan girdiler arasındaki ilişkileri değerlendirecek çalışmaların yapılması tavsiye edilir. 


\section{Kaynakça}

Balkan, F., Çolak, N., Hepbasl1, A., 2005. Performance Evaluation of A Triple Effect $\quad$ Evaporator with Forward Feed Using Exergy Analysis. International Journey Energy Resouces, 29: 455-470.

Bardi, U., Asmar, T., Lavacchi, A., 2013. Turning Electricity into Food: The Role of Renewable Energy in the Future Agriculture, Journal of Cleaner Production, 53: 224-231.

Berthiaume, R., Bouchard, C., 1999. Exergy Analysis of the Environmental Impact of Paving Material Manufacture. Trans CSME, 23(1B): 187-196.

Berthiaume, R., Bouchard, C., Rosen, M.A., 2001. Exergetic Evaluation of the Renewability of a Biofuel. Exergy An International Journal, 4: 256-268.

Çengel, Y.A., Boles, M.A., 2006. In: Thermodynamics an engineering approach. fifth ed.

Dincer, I., Hussain, M.M., AL-Zaharnah, I., 2004. Energy and Exergy Use in Public and Private Sector of Saudi Arabia. Energy Policy, 32: 1615-24.

Eryılmaz, G.A., Kılıç, O., 2018. Türkiye’de Sürdürülebilir Tarım ve İyi Tarım Uygulamaları. Kahramanmaraş Sütçü Imam Üniversitesi Tarım ve Doğa Dergisi, 21(4): 624-631.

Helsel, Z.R., 1992. Energy and alternatives for fertilizer and pesticide use. In: Fluck RC, editor. 6. Energy in farm production. New York: Elsevier, 177-201.

Hoang, D.S., Prasada, R., 2010. Measuring and Decomposing Sustainable Efficiency in Agricultural Production: A Cumulative Exergy Balance Approach. Ecological Economics, 69: 1765-1776.

Kongshaug, G., 1998. Energy Consumption and Greenhouse Gas Emissions in Fertilizer Production. Paper presented at IFA Technical Conference, Marrakech. Morocco September-1 October, 28.

Mohammadshirazi, A., Akram, A., Rafiee, S., Kalhor, E.B., 2015. On the Study of Energy and Cost Analyses of Orange Production in Mazandaran Province. Sustainable Energy Technologies and Assessments, 10: 22-28.

Ozilgen, M., Sorgüven, E.O., 2016. Biothermodynamics. CRC Press.

Ozilgen, M., Sorgüven, E., 2011. Energy and Exergy Utilization, and Carbon Dioxide Emission in Vegetable Oil Production. Energy, 36: 5954-5967.

Öztürk, H.H., Yaşar, B., Eren, Ö., 2010. Tarımda Enerji Kullanımı ve Yenilenebilir Enerji $\quad$ Kullanımı, [http://www.zmo.org.tr/resimler/ekler/ce30eeb956b8bbd_ek.pdf]. Erişim tarihi: 20.10.2018

Pimentel, D., 1991. Ethanol Fuels: Energy, Security, Economics, and The Environment. Journal Agriculture Environment Ethics, 4: 1-13.

Szargut, J., 2005. Exergy Method: Technical and Ecological Applications. WIT Press, Southampton, Boston

Taki, M., Yildizhan, H., 2018. Evaluation The Sustainable Energy Applications for Fruit and Vegetable Productions Processes; Case study: Greenhouse Cucumber Production. Journal of Cleaner Production, 199: 164-172.

Taşkın, O., Vardar, A., 2016. Tarımsal Üretimde Bazı Yenilenebilir Enerji Kaynakları～Kullanımı. Uludağ Üniversitesi Ziraat Fakültesi Dergisi, 30(1): 179-184.

Wall, G., 2003. Exergy Tools. Proc Inst Mech Eng, 125-136.

Wittmus, H., Olson, L., Lane, D., 1975. Energy Requirements for Conventional Versus Minimum Tillage. Journal Soil Water Conservation, 3: 72-75.

Yildizhan, H., 2018. Energy, Exergy Utilization and $\mathrm{CO}_{2}$ Emission of Strawberry Production in Greenhouse and Open Field. Energy, 143: 417-423.

Yildizhan, H., Taki, M., 2018. Assessment of Tomato Production Process by Cumulative Exergy Consumption Approach in Greenhouse and Open Field Conditions: Case Study of Turkey. Energy, 156: 401-408.

Yildizhan, H., 2017. Thermodynamics Analysis For A New Approach to Agricultural Practices: Case of Potato Production. Journal of Cleaner Production, 166: 660-667. 